\title{
Additional Preoperative Parameters to Enable the Decision of Partial Orchiectomy in Small Testicular Masses
}

\section{Küçük Testiküler Kitlelerde Parsiyel Orşiektomi Kararını Vermeyi Sağlayacak Ek Preoperatif Parametreler}

\author{
(i) İsmail SELVİ1, id Halil BAŞAR²
}

${ }^{1}$ Karabük University Training and Research Hospital, Clinic of Urology, Karabük, Turkey

${ }^{2}$ University of Health Science, Dr. Abdurrahman Yurtaslan Ankara Oncology Training and Research Hospital, Clinic of Urology, Ankara,

Turkey

\section{ABSTRACT}

Objective: We aimed to determine the predictive value of additional parameters for differentiating benign-malign tumors and to identify optimal patients for partial orchiectomy in unilateral, small $(\leq 2 \mathrm{~cm})$ testicular masses.

Methods: The data of 31 patients who underwent radical orchiectomy between January 2010 and December 2017 due to unilateral and small testicular masses were retrospectively analyzed. Demographic data, histopathological tumor types, serum tumor markers, neutrophil/lymphocyte ratio (NLR), monocyte/ lymphocyte ratio (MLR), platelet/lymphocyte ratio (PLR), mean platelet volume (MPV), red cell distribution width (RDW), the presence of testicular dysgenesis syndrome (TDS) and its components, postoperative follow-up outcomes were recorded. Patients were divided into two groups as benign and malignant.

Results: There was no significant difference between groups in terms of AFP $(p=0.116), \beta-h C G \quad(p=0.205), \operatorname{LDH}(p=0.606)$, MPV ( $\mathrm{p}=0.087)$ and RDW ( $\mathrm{p}=0.266)$; while MLR ( $\mathrm{p}=0.001)$, NLR ( $\mathrm{p}=0.036)$ and PLR ( $\mathrm{p}=0.001)$ were significantly higher in malignant group. The presences of testicular microlithiasis $(\mathrm{p}=0.719)$, undescended testis $(\mathrm{p}=0.254)$, hypospadias $(\mathrm{p}=0.645)$, atrophic testis $(\mathrm{p}=0.409)$ were not different between groups; while the rate of disorders of semen parameters $(\mathrm{p}=0.043)$ and presence of TDS ( $p=0.043$ ) were significantly higher in malignant cases.
ÖZ

Amaç: Tek taraflı, küçük $(\leq 2 \mathrm{~cm})$ testiküler kitlelerin preoperatif değerlendirmesinde, benign-malign ayrımını yapabilmede kullanılabilecek ek klinik parametrelerin öngörü değerini araştırarak, parsiyel orşiektomi uygulanabilecek hastaları belirlemeyi amaçladık.

Yöntemler: Ocak 2010-Aralık 2017 tarihleri arasında radikal orşiektomi yapılan tek taraflı, küçük testiküler kitleye sahip 31 hastanın verileri retrospektif olarak incelendi. Hastaların demografik verileri, histopatolojik tümör tipleri, serum tümör belirteçleri, nötrofil/lenfosit oranı (NLR), monosit/lenfosit oranı (MLR), platelet/lenfosit oranı (PLO), ortalama platelet hacmi (MPV), eritrosit dağılım genişliği (RDW), testiküler disgenezis sendromu (TDS) ve bileşenlerinin varlı̆̆ı, postoperatif takip verileri kaydedildi. Hastalar tümör histopatolojisine göre benign ve malign olarak iki gruba ayrılarak karşılaştırıldı.

Bulgular: Ortalama tanı yaşı 29,39 $\pm 5,90$ olan 31 hastanın 11 'i benign, 20'si malign patolojiye sahipti. İki grup arasında AFP $(\mathrm{p}=0,116), \beta-\mathrm{hCG}(\mathrm{p}=0,205), \mathrm{LDH}(\mathrm{p}=0,606), \mathrm{MPV}(\mathrm{p}=0,087)$ ve $\mathrm{RDW}(\mathrm{p}=0,266)$ açısından anlamlı fark görülmezken; malign grupta MLR ( $\mathrm{p}=0,001)$, NLR ( $\mathrm{p}=0,036)$ ve PLR ( $\mathrm{p}=0,001)$ anlamlı olarak daha yüksekti. Testiküler mikrolitiazis $(\mathrm{p}=0,719)$, inmemiş testis $(\mathrm{p}=0,254)$, hipospadias $(\mathrm{p}=0,645)$, atrofik testis $(\mathrm{p}=0,409)$ saptanma oranları gruplar arasında farklılık göstermezken; semen parametresi bozukluğu oranı $(\mathrm{p}=0,043)$ ve TDS varlığı $(\mathrm{p}=0,043)$ malign olgularda belirgin olarak yüksek bulundu. Çok değişkenli
Address for Correspondence: İsmail SELVi, Karabük University Training and Research Hospital, Clinic of Urology, Karabük, Turkey

E-mail: ismselvi33@hotmail.com ORCID ID: orcid.org/0000-0003-3578-0732
Received: 24.04 .2019

Accepted: 12.07.2019

Cite this article as: Selvi i, Başar H. Additional Preoperative Parameters to Enable the Decision of Partial Orchiectomy in Small Testicular Masses. Bezmialem Science 2020;8(1):48-55. 
In multivariate analysis, MLR and PLR were found as predictive factors for benign-malign distinction of small testicular masses.

Conclusion: In the patients in whom preoperative malignancy suspicion could not be excluded, we think that PLR, MLR, NLR, disorders of semen parameters and presence of TDS may have high predictive value for benign-malign distinction. Partial orchiectomy may be recommended in patients with suspicion of benign lesions according to these parameters.

Keywords: Partial orchiectomy, serum hemogram parameters, small testicular masses, testicular dysgenesis syndrome analizde, MLR ve PLO'nun $\leq 2 \mathrm{~cm}$ boyutlu testiküler kitlelerde malignbenign ayrımını öngörmede prediktif faktörler olduğunu gözledik.

Sonuç: Preoperatif olarak malignite şüphesinin dışlanamadığ 1 olgularda, PLO, MLR, NLR, semen parametresi bozuklukları ve TDS varlığının benign-malign ayrımını yapma gücünün yüksek olabileceğini; benign olma olasılığı yüksek olgularda, parsiyel orşiektominin önerilebileceğini düşünmekteyiz.

Anahtar Sözcülkler: Parsiyel orşiektomi, serum hemogram parametreleri, küçük testiküler kitleler, testiküler disgenezis sendromu

\section{Introduction}

Testicular germ cell tumor (TGCT) is a relatively rare neoplasm that accounts for $1-2 \%$ of all malignancies (1), but is the most common genitourinary malignancy detected, especially in males between the ages of 15-44. It accounts for $98 \%$ of all testicular malignancies (2). The standard approach to treatment is radical orchiectomy. As a result of the developments in chemotherapy (CT) applications in recent years, high cure rates are provided in patients with TGCT. However, adjuvant CT or radiotherapy (RT) applied with orchiectomy and its continuation may lead to a decrease in fertility rates in this young male population. In addition, due to the lack of testosterone production caused by testicular loss; decrease in sexual function, deterioration in mascular body structure, osteoporosis due to decrease in bone mineral density can be seen in the following years $(3,4)$.

Testicular sparing surgery has been introduced to protect fertility rates and testosterone levels. Partial orchiectomy for this purpose is recommended only in patients with bilateral testicular tumors or in the presence of a tumor in the solitary testis, if the testosterone level is normal and the tumor size is $<2$ $\mathrm{cm}(4,5)$. Since the majority of testicular masses have malignant characteristics, this approach is not recommended in patients with stable contralateral testis, with the concern that the chance of cure may be reduced in patients with inadequate or incomplete resection (5).

Most of the palpable masses detected in the physical examination, which is the first approach to diagnosis of testicular masses, are large in diameter $(>2 \mathrm{~cm})$. Although scrotal ultrasonography (USG) used as imaging method increases the accuracy of diagnosis, the exact diagnosis is made by orchiectomy following inguinal exploration (3). However, the diagnosis-treatment algorithm to be applied in small testicular masses that are not easily palpable and detected only by USG is still a subject of debate (6). Benign pathology has been reported in $60-80 \%$ of small testicular masses with normal tumor markers, and current studies suggest that radical orchiectomy is an extreme treatment in these cases $(4,6,7)$. As a result, we have seen recent studies advocating the applicability of partial orchiectomy in small, unilateral tumors $(6,8)$.

Since our knowledge on diagnostic and therapeutic approach to be applied in unilateral, small $(\leq 2 \mathrm{~cm})$ testicular masses is still controversial, in this study, we aimed to investigate the predictive value of additional parameters that can improve diagnostic accuracy in preoperative evaluation by examining clinical-pathological characteristics of benign and malignant cases diagnosed in our clinic.

\section{Methods}

The pathological data and oncological results of 96 patients who were admitted in our clinic between January 2010-December 2017 due to testicular mass and were treated with radical orchiectomy for suspected malignancy after physical examination, measurement of tumor markers, scrotal ultrasonography and even magnetic resonance imaging (MRI) were performed, were evaluated retrospectively. Among 74 patients with histopathological diagnosis of TGCT and 13 patients with all other benign pathologies, 31 patients with pathological tumor diameter $\geq 2 \mathrm{~cm}$ and whose treatment and follow-up data could be fully accessed were included in the study. A total of 31 patients, 20 of whom had TGCT and 11 with benign pathology, were analyzed. All the procedures in our study were carried out in accordance with the principles of the Helsinki Declaration and this study was not approved by the Ethics Committee due to its retrospective design.

Demographic data of the patients (age), clinical findings (undescended testis, hypospadias, atrophic testis with testicular volume $<12 \mathrm{~mL}$, testicular microlithiasis, semen parameter disorders), histopathological features (tumor subtypes, clinical tumor stage, tumor size, pathological prognostic factors of tumor), serum levels of tumor markers [alpha-fetoprotein (AFP), beta human chorionic gonadotropin ( $\beta$-hCG), lactate dehydrogenase (LDH)], hemogram, serum parameters [(neutrophil/lymphocyte ratio (NLR), monocyte/lymphocyte ratio (MLR), platelet/lymphocyte ratio (PLO), mean platelet volume (MPV), erythrocyte distribution width (RDW)], oncological results (follow-up duration after orchiectomy, local recurrence, distant metastasis and cancer-specific mortality rates) were recorded.

In the presence of oligospermia [hazard ratio (HR): 11.9], decreased vitality (HR: 6.6), impaired sperm morphology (HR: 4.2), or low numbers of total motile sperm (HR: 6.9), it is known that there is a higher risk of testicular cancer (9). Therefore, we 
evaluated the patients, in whom we detected any impairment in semen parameters in terms of number, motility, morphology or vitality, as decreased spermatogenesis. The definition of testicular dysgenesis syndrome (TDS) includes the presence of at least two components of the undescended testicle, hypospadias, decreased spermatogenesis, atrophic testis and TGCT. In preoperative evaluation, we considered four parameters other than TGCT when describing the presence of preoperative TDS, since it would not be possible to know if TGCT was present in the testicular mass in patients without pathology results. Based on anamnesis and clinical examination findings, we evaluated patients with at least two of these four clinical findings as TDS.

Clinical tumor stages of patients with TGCT were evaluated according to the 2009 tumor-node-metastasis classification and histopathological tumor subtypes according to the World Health Organization's classification. Pathological prognostic risk factors were assessed as set out in the European Association of Urology 2019 guideline. Accordingly, the presence of Rete testis involvement and tumor size greater than $4 \mathrm{~cm}$ in seminomas; the presence of lymphovascular invasion, the percentage of embryonal carcinoma $>50 \%$ and the proliferation rate $>70 \%$ in non-seminomas were noted as poor prognostic factors (5). However, in all patients in our study, the tumor size was $\leq 2 \mathrm{~cm}$.

Patients were divided into two groups, benign and malignant, according to tumor histopathology. Eleven patients with benign pathological diagnosis were classified as group I and 20 patients with TGCT diagnosis were classified as group II. Both groups were compared in terms of clinical findings, prognostic risk factors, serum hemogram parameters and oncological outcomes.

\section{Statistical Analysis}

To compare the differences between the two groups, normality status was evaluated with Kolmogorov-Smirnov and ShapiroWilk tests. Pearson chi-square or Fisher's exact test was used for categorical variables; independent sample t-test or MannWhitney $U$ test was used for continuous variables. The KaplanMeier method could not be used because there were not enough cases to perform survival analysis in the malignant group. Univariate and multivariate logistic regression analyses were used to determine the predictive factors that could predict malignantbenign mass differentiation. The analyses were done using IBM SPSS Statistics 21 (IBM, Armonk, NY USA) software. $\mathrm{P}<0.05$ was considered statistically significant.

\section{Results}

The mean age of diagnosis of 31 patients with tumor size $\leq 2$ $\mathrm{cm}$ was $29.39 \pm 5.90$ years. In total, TGCT was detected in 20 patients, while histopathology of 11 patients was benign. Detected benign testicular tumors were epidermoid cyst $(n=2$, $18.2 \%)$, myofibroblastic inflammatory tumor $(\mathrm{n}=2,18.2 \%)$, benign cystic teratoma $(n=3,27.2 \%)$, benign Leydig cell tumor $(\mathrm{n}=2,18.2 \%)$, and fibroma $(\mathrm{n}=2,18.2 \%)($ Table 1$)$.

In a median 44-month (9-117) follow-up, only in a single case with stage IIIC nonseminoma, recurrence in retroperitoneum and visceral metastasis in the lung were observed 4 months after orchiectomy and cancer-specific mortality occurred 9 months after the diagnosis despite adjuvant CT was given. The pathological characteristics and oncological outcomes of all patients are shown in Table 1.

There were no significant differences between the benign and malignant groups in terms of AFP ( $\mathrm{p}=0.116), \beta-\mathrm{hCG}(\mathrm{p}=0.205)$ and LDH $(\mathrm{p}=0.606)$, which were tumor markers evaluated in the preoperative period. MLR ( $\mathrm{p}=0.001)$, NLR $(\mathrm{p}=0.036)$ and

Table 1. The pathological characteristics and oncological outcomes of testicular masses

\begin{tabular}{|c|c|c|}
\hline Parameters & $\begin{array}{l}\text { Group I }(n=11) \\
\text { benign }\end{array}$ & $\begin{array}{l}\text { Group II } \\
(n=20) \\
\text { malignant }\end{array}$ \\
\hline \multicolumn{3}{|l|}{$\begin{array}{l}\text { Histopathological tumor } \\
\text { type }(n, \%)\end{array}$} \\
\hline -Seminom & & $10(50.0)$ \\
\hline -Non-seminom & - & $8(40.0)$ \\
\hline -Mixed & - & $2(10.0)$ \\
\hline -Epidermoid cyst & - & \\
\hline $\begin{array}{l}\text { - Inflammatory } \\
\text { myofibroblastic tumor }\end{array}$ & $2(18.2)$ & $\begin{array}{l}- \\
-\end{array}$ \\
\hline - Benign cystic teratoma & $2(18.2)$ & - \\
\hline $\begin{array}{l}\text { - Benign Leydig cell } \\
\text { tumor }\end{array}$ & $3(27.2) \quad 2(18.2) \quad 2(18.2)$ & - \\
\hline -Fibroma & & \\
\hline \multicolumn{3}{|l|}{ Tumor stage $(n, \%)$} \\
\hline IA & - & $7(35.0)$ \\
\hline IB & - & $7(35.0)$ \\
\hline IS & - & $0(0.0)$ \\
\hline IIA & - & $1(5.0)$ \\
\hline IIB & - & $1(5.0)$ \\
\hline IIC & - & $0(0.0)$ \\
\hline IIIA & - & $0(0.0)$ \\
\hline IIIB & - & $1(5.0)$ \\
\hline IIIC & - & $3(15.0)$ \\
\hline $\begin{array}{l}\text { Intratubular germ cell } \\
\text { neoplasia }(n, \%)\end{array}$ & - & $13(65.0)$ \\
\hline $\begin{array}{l}\text { Rete testis involvement } \\
(n, \%)\end{array}$ & - & $7(35.0)$ \\
\hline $\begin{array}{l}\text { Lymphovascular } \\
\text { invasion }(n, \%)\end{array}$ & - & $6(30.0)$ \\
\hline $\begin{array}{l}\text { Rate of embryonal } \\
\text { carcinoma }>50 \%(n, \%)\end{array}$ & - & $6(30.0)$ \\
\hline $\begin{array}{l}\text { Proliferation rate }>70 \% \\
(n, \%)\end{array}$ & - & $2(10.0)$ \\
\hline $\begin{array}{l}\text { Local recurrence rate } \\
(n, \%)\end{array}$ & - & $1(5.0)$ \\
\hline $\begin{array}{l}\text { Distant metastasis rate } \\
(\mathrm{n}, \%)\end{array}$ & - & $1(5.0)$ \\
\hline $\begin{array}{l}\text { cancer-specific mortality } \\
\text { rate }(\%)\end{array}$ & - & $1(5.0)$ \\
\hline
\end{tabular}


PLR $(\mathrm{p}=0.001)$ were significantly higher in the malignant group, while there were no differences between the groups in terms of MPV ( $\mathrm{p}=0.087)$ and RDW ( $\mathrm{p}=0.266)$ (Table 2).
Although the detection rates of testicular microlithiasis $(\mathrm{p}=0.719)$, the rates of undescended testis $(\mathrm{p}=0.254)$, hypospadias $(\mathrm{p}=0.645)$ and atrophic testis $(\mathrm{p}=0.409)$ were higher

Table 2. Demographic and clinical data of patients

\begin{tabular}{|c|c|c|c|c|}
\hline Parameters & Group $1(n=11)$ & Group 2 (n=20) & Total $(n=31)$ & $\mathrm{p}$ \\
\hline \multicolumn{5}{|l|}{ Age } \\
\hline Average \pm standard deviation & $28.27 \pm 5.14$ & $30.00 \pm 6.32$ & $29.39 \pm 5.90$ & t0.445 \\
\hline \multicolumn{5}{|l|}{ Tumor diameter $(\mathrm{cm})$} \\
\hline Average \pm standard deviation & $1.61 \pm 0.27$ & $1.55 \pm 0.29$ & $1.57 \pm 0.28$ & †0.530 \\
\hline \multicolumn{5}{|l|}{ Tumor side $(n, \%)$} \\
\hline -Left & $5(45.5)$ & $11(55.0)$ & $16(51.6)$ & $\neq 0.611$ \\
\hline -Right & $6(54.5)$ & $9(45.0)$ & $15(48.4)$ & \\
\hline $\operatorname{AFP}(\mathrm{ng} / \mathrm{mL})$ & 1.50 & 2.05 & 1.80 & \\
\hline Median (25.-75. percentile) & $(1.20-2.70)$ & $(1.52-7.45)$ & $(1.30-5.70)$ & $\$ 0.116$ \\
\hline$\beta$-hCG (mIU/mL) & 1.50 & 2.25 & 1.50 & \\
\hline Median (25.-75. percentile) & $(0.00-1.60)$ & $(0.22-31.40)$ & $(0.10-4.50)$ & $80 . \angle 05$ \\
\hline LDH (U/L) & 165.00 & 183.50 & 167.00 & \\
\hline Median (25.-75. percentile) & $(132.00-202.00)$ & $(143.00-220.50)$ & $(140.00-210.00)$ & su. \\
\hline \multicolumn{5}{|l|}{ Monocyte/lymphocyte ratio (MLR) } \\
\hline (Average \pm standard deviation) & $0.19 \pm 0.07$ & $0.32 \pm 0.10$ & $0.28 \pm 0.11$ & t0.001* \\
\hline Neutrophil/lymphocyte ratio (NLR) & 1.67 & 2.35 & 2.12 & \\
\hline Median (25.-75. percentile) & $(1.33-2.12)$ & $(1.55-4.19)$ & $(1.38-3.39)$ & $\S 0.036^{*}$ \\
\hline \multicolumn{5}{|l|}{ Platelet/lymphocyte ratio (PLO) } \\
\hline (Average \pm standard deviation) & $94.33 \pm 21.29$ & $162.12 \pm 58.54$ & $138.06 \pm 58.38$ & t0.001* \\
\hline Mean platelet volume (fL) (MPV) & 3.12 & 3.91 & 3.75 & \\
\hline Median (25.-75. percentile) & $(2.67-4.15)$ & $(3.22-5.18)$ & $(3.08-4.44)$ & $\S 0.087$ \\
\hline \multicolumn{5}{|l|}{ Red cell distribution width (fL) (RDW) } \\
\hline (Average \pm standard deviation) & $13.24 \pm 0.72$ & $13.70 \pm 1.22$ & $13.54 \pm 1.08$ & t0.266 \\
\hline \multicolumn{5}{|c|}{ Presence of testicular microlithiasis $(n, \%)$} \\
\hline Yes & $1(9.1)$ & $2(10.0)$ & $3(9.7)$ & \\
\hline No & $10(90.9)$ & $18(90.0)$ & $28(90.3)$ & १0.719 \\
\hline \multicolumn{5}{|l|}{ Undescended testis $(n, \%)$} \\
\hline Yes & $0(0.0)$ & $3(15.0)$ & $3(9.7)$ & \\
\hline No & $11(100.0)$ & $17(85.0)$ & $28(90.3)$ & 90.254 \\
\hline \multicolumn{5}{|l|}{ Disorder of semen parameter $(n, \%)$} \\
\hline Yes & $0(0.0)$ & $6(30.0)$ & $6(19.4)$ & $\pm 0043 *$ \\
\hline No & $11(100.0)$ & 14(70.0) & $25(80.6)$ & $\neq 0.043^{*}$ \\
\hline \multicolumn{5}{|l|}{ Hypospadias $(n, \%)$} \\
\hline Yes & $0(0.0)$ & $1(5.0)$ & $1(3.2)$ & 90645 \\
\hline No & $11(100.0)$ & 19(95.0) & $30(96.8)$ & 70.645 \\
\hline \multicolumn{5}{|l|}{ Atrophic testis $(n, \%)$} \\
\hline Yes & $0(0.0)$ & $2(10.0)$ & $2(6.5)$ & \\
\hline No & $11(100.0)$ & $18(90.0)$ & 29 (93.5) & 90.409 \\
\hline \multicolumn{5}{|l|}{ Presence of TDS $(n, \%)$} \\
\hline Yes & $0(0.0)$ & $6(30.0)$ & $6(19.4)$ & $\neq 0.043^{*}$ \\
\hline No & $11(100.0)$ & $14(70.0)$ & $25(80.6)$ & $+0.043^{3}$ \\
\hline
\end{tabular}


in the malignant group, these differences were not statistically significant. Impairment rate of semen parameters $(p=0.043)$ and presence of TDS $(\mathrm{p}=0.043)$ were significantly higher in patients with TGCT (Table 2).

Due to the low number of patients in both groups, ROC analysis could not be performed to determine the predictive values for hemogram parameters. Instead, median values were used as predictive values. According to our analysis, we determined the predictive values as 0.27 for MLR, 2.12 for NLR and 124.04 for PLO.

In univariate analysis, MLR, NLR, PLO, semen parameter disorders and presence of TDS were found as independent predictive factors in predicting benign-malignant differentiation in testicular masses with size $\leq 2 \mathrm{~cm}$. In multivariate analysis, we observed that PLR and MLR were more significant (Table 3).

\section{Discussion}

It is known that hypogonadism develop in 10-20\% of patients after radical orchiectomy. For this reason, partial orchiectomy is a treatment strategy that has been tried to be popularized in order to protect fertility, reduce the need for lifelong androgen supplementation and psychosexual problems that may occur, especially in young patients without children (8). It was stated that sufficient Leydig cell reserves could be maintained to ensure testosterone production with partial orchiectomy (8). However, the main drawback in this practice is insufficient or incomplete resection of the tumor due to microinvasions that may be overlooked. In addition, the high rate of detection of intratubular germ cell neoplasia (ITGCN), a precancerous lesion that accompanies tumors in the peripheral testicular parenchyma, also limits the applicability of partial orchiectomy in every case (11). However, there are also studies advocating the application of this method in well-selected cases $(3,8)$. Bojanic et al. detected local recurrence in one $(11.1 \%)$ patient who underwent partial orchiectomy in median 45-month follow-up of 9 patients (12). Xiao et al. (8) reported that in the median 78-month follow-up, oncological results were similar in patients who underwent radical orchiectomy and those who underwent partial orchiectomy, but fertility rates were better maintained in the follow-up in the patients who underwent partial orchiectomy.

The main problem with small testicular masses is the application of radical orchiectomy because those with benign pathology cannot be distinguished in preoperative examination. In recent years, clinical diagnostic accuracy of testicular tumors has greatly increased thanks to advances in diagnostic imaging techniques such as USG and MRI, in addition to serum tumor markers (5). However, due to its low incidence, there are still no predictive models with high predictive value in making the benign-malignant tumor distinction. Preoperative biopsy is not recommended because there may be tumor seeding.

The most important stage in partial orchiectomy applied to small testicular masses is intraoperative frozen examination following inguinal exploration. Intraoperative histopathological diagnosis can be made in this way. In various publications, the sensitivity of frozen examination to detect benign tumors was stated as $81-90 \%$ and specificity as $99-100 \%$; sensitivity to detect malignant tumors was found as $93-100 \%$, specificity as $98-100 \%$, positive predictive value as $94.2 \%$, negative predictive value as $92.6 \%(3,13,14)$. However, in some tumors with very small size $(<8 \mathrm{~mm})$, it may be difficult to obtain enough tissue samples for frozen examination. In addition, it is not easy to distinguish benign and malignant tumors in some pathologies such as Sertoli cell tumor, Leydig cell tumor, epidermoid cyst, Brenner tumor, testicular tubular adenomas (6). For this reason, one of the accepted approaches is to perform radical orchiectomy in patients who have malignancy as a result of frozen examination (7).

Song et al. (11) detected benign tumors in 24\% of 325 patients who underwent radical orchiectomy with suspicion of TGCT. They showed that the increase in tumor size increased the risk of malignancy (for a $1 \mathrm{~cm}$ increase in tumor size, $\mathrm{HR}=1.284$, $\mathrm{p}=0.036)$. However, since the mean tumor diameter was $4.9 \pm 0.2$ $(\min =0.5-\max =230 \mathrm{~cm})$ in the patients included in that study, it was not a study evaluating the benign-malignant separation in small testicular masses. Examining publications in the literature, Shilo et al. (15) reported that $38.5 \%$ of tumors smaller than

\section{Table 3. Factors predicting malignancy in small testicular masses}

\section{Univariate model}

MLR $>0.27$
NLR $>2.12$
PLO $>124.04$
Semen parameter disorder
Presence of testicular dysgenesis

syndrome

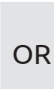

6.222

8.357

23.333

1.929

3.333
$95 \% \mathrm{Cl}$

Lower

1.212

1.400

2.417

0.317

0.337

\begin{tabular}{|l|l|}
\hline Upper & $p$ \\
\hline 31.937 & $0.028^{*}$ \\
49.883 & $0.020 *$ \\
225.223 & $0.006^{*}$ \\
11.739 & $0.025^{*}$ \\
\hline 32.959 & $0.033^{*}$ \\
\hline
\end{tabular}

MLR: Monocyte/lymphocyte ratio, NLR: Neutrophil/lymphocyte ratio, PLO: Platelet/lymphocyte ratio ${ }^{*} \mathrm{p}<0.05$ shows a statistically significant difference, OR: Odds ratio, Cl: Confidence interval Logistic regression analysis

\section{Multivariate model}

\begin{tabular}{|c|c|c|c|}
\hline \multirow{2}{*}{ OR } & \multicolumn{2}{|l|}{$95 \% \mathrm{Cl}$} & \multirow{2}{*}{$p$} \\
\hline & Lower & Upper & \\
\hline 14.118 & 1.239 & 160.936 & $0.033^{*}$ \\
\hline 23.333 & 2.417 & 225.223 & 0.006 * \\
\hline
\end{tabular}


$18.5 \mathrm{~mm}$ in size and $2 \%$ of tumors of larger size were benign. In other $60-77 \%$ of tumors smaller than $20 \mathrm{~mm}$ were benign, while this rate rised to $80 \%$ in masses less than $5 \mathrm{~mm}(3,16)$. On the other hand, the incidence of benign pathology in paediatric patients has been reported to increase up to $74 \%$, and testicular protective surgical approach is more on the agenda, especially in the puberty and postpubertal age groups (4). We found that $35.4 \%$ of 31 patients with testicular mass size $\leq 2 \mathrm{~cm}$ received a benign diagnosis.

Song et al. reported that the increase in $\beta$-hCG values, regardless of tumor size, was a strong determinant in predicting malignant testicular masses $(\mathrm{HR}=10.550, \mathrm{p}<0.001)$ and that $\mathrm{AFP}$ was not effective in making this distinction ( $p>0.05)$ (11). They showed that the AFP level was normal in patients with seminoma and that seminoma was detected in $44.5 \%$ of cases. We found no significant difference between benign and malignant groups in terms of all three tumor markers in a more specific subgroup with tumor size $\leq 2 \mathrm{~cm}$. This finding suggests that the use of tumor markers in terms of predicting malignancy may not be useful, especially in preoperative clinical evaluation of small testicular masses.

The most commonly used method in clinical evaluation today is the combination of scrotal gray scale USG and colored doppler USG. Evaluation of tumor diameter, parenchyma echogenity and testicular blood flow may be decisive in the differential diagnosis of malignancy $(17,18)$. In this low-cost, easily accessible, non-invasive method, increased blood flow $(\mathrm{HR}=3.320, \mathrm{p}<0.001)$ and decreased parenchyma echogenity ( $H R=3.191, p=0.001)$ were reported to be decisive for malignant masses (11). Although the sensitivity of colored doppler USG is high in small testicular masses, its specificity is very low, which may lead to the accidental evaluation of benign masses as malignant (7). In suspected cases where USG is insufficient, MRI and contrast-enhanced ultrasound may be the guide with high accuracy rates for determining tumoral blood flow, with the advantage of evaluating soft tissues. However, these methods are not easy to reach everywhere (19). Ates et al. (7) detected TGCT in $6.7 \%$ of 15 testicular masses $<25 \mathrm{~mm}$ in size. They performed partial orchiectomy, because they excluded suspicion of malignancy by preoperative clinical evaluation. This suggests that more reliable parameters are needed in clinical evaluation. In our study, although scrotal USG, doppler USG and scrotal MRI were performed due to suspected malignancy in $\leq 2 \mathrm{~cm}$ sized masses, radical orchiectomy was performed because the possibility of malignancy could not be ruled out. In 11 (35.4\%) of 31 patients, the histopathological diagnosis was benign and perhaps unnecessary organ loss was experienced in these patients. This leads us to the search for better diagnostic parameters.

In recent years, several studies have been reported evaluating the relationship between inflammatory markers, hemogram parameters, and oncological outcomes in patients with genitourinary cancer. In TGCT, the effects of NLR and platelet levels on disease prognosis, metastasis development, and diseasespecific survival have been studied in some studies (20-22). Platelets have been shown in various animal experiments to affect the immune system by secreting various bioactive molecules and cytokines, contributing to tumor proliferation and metastasis development $(23,24)$. We, on the other hand, evaluated the reliability of various non-invasive hemogram parameters in making benign-malignant separation in $\leq 2 \mathrm{~cm}$ sized testicular masses, unlike those reported in the literature. According to our findings, the predictive values were 0.27 for MLR, 2.12 for NLR and 124.04 for PLO. We predict that the masses with values higher than those predictive values are more likely to be malignant. We were unable to show that MPV and RDW values were significant in predicting the presence of malignancy.

Embryonal hormonal disorders associated with androgens are thought to lead to abnormal differentiation in primordial germ cells and gonocytes (25). Based on this hypothesis, disorders in androgen production and receptor expression and exposure to anti-androgenic or estrogenic effects have been shown to negatively affect genitourinary system development in animal experiments $(26,27)$. Impairment in testicular differentiation and development provides the basis for irreversible genital malformations (such as hypospadias and undescended testicles), impaired spermatogenesis, and development of TGCT (28). All of these abnormalities called TDS include the components of undescended testis, hypospadias, decreased spermatogenesis, atrophic testis and TGCT components. It is stated that testicular dysgenesis may occur in the presence of at least two of these pathologies (10). Since it is known that the undescended testis and decreased spermatogenesis, two of these components, are also predisposing factors in the development of TGCT; patients with TDS with these components are more likely to be accompanied by TGCT. In our study, only the decreased spermatogenesis rate, which was one of TDS-forming components, was significantly higher in the malignant group, while the incidence of TDS was higher in the malignant group. Decreased spermatogenesis and the presence of TDS were also determined as independent predictive factors for malignancy in univariate analysis. Our findings coincided with publications reporting that testicular neoplasia was more common in patients with impaired spermatogenesis and that male infertility might be a biomarker for testicular malignancies $(9,28)$.

Of patients undergoing radical orchiectomy, $80-90 \%$ have simultaneous ITGCN in adjacent testicular tissue (29). This suggests that ITGCN would be more likely to be present in the peripheral testicular parenchyma next to the excised tumor during partial orchiectomy. For this reason, taking biopsy from peripheral parenchyma and even from contralateral testis during partial orchiectomy is recommended and 20 Gy adjuvant RT is recommended in patients with ITGCN (5). In thirteen (65\%) of the 20 patients with TGCT included in our study, ITGCN was detected, while in four $(30.8 \%)$ of these thirteen patients the presence of TDS was observed. ITGCN was observed in four $(66.7 \%)$ of six patients with TDS. This finding showed us that if partial orchiectomy was planned, it would be necessary to obtain a biopsy from the peripheral testicular parenchyma as well as a frozen tissue examination from the tumor base and to ensure the presence of ITGCN; if there was a presence of TDS in 
the patient's anamnesis during preoperative evaluation, ITGCN detection rate might be higher.

Testicular microlithiasis is a rare condition detected by chance in the scrotal USG. It is often asymptomatic and seen at a rate of $2.4-5.6 \%$. The incidence rate in men with scrotal symptoms is $0.6-9.0 \%$ (28). The incidence rate may be up to $18.1 \%$ in the presence of accompanying pathologies such as undescended testicles, atrophic testicles, or infertility, while the rate is $6-46 \%$ in the presence of accompanying TGCT (30). Although the presence of testicular microlithiasis alone does not carry a risk for malignancy, there is an increased risk for development of TGCT in the presence of an accompanying history of TGCT, undescended testis, testicular atrophy and infertility. This risky group requires close monitoring (30). In our study, we observed testicular microlithiasis in $9.7 \%$ of 31 patients in total, consistent with the literature. The incidence rate did not differ significantly between benign (9.1\%) and malignant (10\%) cases.

\section{Study Limitations}

The retrospective design of our study, the inability to perform randomization, the limited statistical analysis due to the low number of patients, short follow-up durations and the fact that the follow-up results belonging to one center are the main limiting factors.

\section{Conclusion}

Although benign pathology is high in small $(\leq 2 \mathrm{~cm})$, unilateral testicular masses with normal levels of tumor markers and contralateral intact testis, the suggestion of testicular protective approach is still not accepted. However, in cases where preoperative imaging methods cannot clearly rule out the suspicion of malignancy, we think that increased PLR and MLR levels may be more reliable, as well as increased NLR level, semen parameter disorders and the presence of TDS may have high ccuracy to predict malignancy. Therefore, using these parameters, we argue that partial orchiectomy, which is a fertility and organ sparing approach, may be recommended in cases with high probability of benign tumor. However, we believe that our findings should be supported by other prospective, randomized, controlled, multicenter studies with larger number of patients and longer follow-up durations.

\section{Ethics}

Ethics Committee Approval: All the procedures in our study were carried out in accordance with the principles of the Helsinki Declaration and this study was not approved by the Ethics Committee due to its retrospective design.

Informed Consent: A consent form was completed by all participants.

Peer-review: Externally peer reviewed.

\section{Authorship Contributions}

Concept: İ.S., H.B., Design: İ.S., H.B., Data Collection or Processing: İ.S., H.B., Analysis or Interpretation: İ.S., H.B., Literature Search: İ.S., H.B., Writing: İ.S., H.B.
Conflict of Interest: No conflict of interest was declared by the authors.

Financial Disclosure: The authors declared that this study received no financial support.

\section{References}

1. Siegel RL, Miller KD, Jemal A. Cancer statistics. Cancer J Clin 2017;67:7-30.

2. McGlynn KA, Cook MB. Etiologic factors in testicular germ-cell tumors. Future Oncol 2009;5:1389-402.

3. Khan MJ, Bedi N, Rahimi MNC, Kalsi J. Testis sparing surgery for small testicular masses and frozen section assessment. Cent European J Urol 2018;71:304-9.

4. La Rocca R, Capece M, Spirito L, Cumberbatch MK, Creta M, Altieri $\mathrm{V}$, et al ; EAU-ESRU (European Associations of Urology-European Society of Residents Urologist). Testis-sparing surgery for testicular masses: current perspectives. Minerva Urol Nefrol 2019;71:359-64.

5. Laguna MP, Albers P, Albrecht W, Algaba F, Bokemeyer C, Boormans JL, et al. European Association of Urology guidelines on testicular cancer: the 2019 Update. European Urology 2019;75:799-810.

6. Galosi AB, Fulvi P, Fabiani A, Servi L, Filosa A, Leone L, et al. Testicular sparing surgery in small testis masses: A multinstitutional experience. Arch Ital Urol Androl 2016;88:320-4.

7. Ates F, Malkoc E, Zor M, Demirer Z, Alp BF, Basal S, et al. Testis Sparing Surgery in Small Testicular Masses With No Malignancy Suspicion. Clin Genitourin Cancer 2016;14:e49-53.

8. Xiao F, Shi JZ, Liu Y, Liu T, Wang J, Liu YS, et al. Radical and testis-sparing surgery for primary testicular tumors: A single-center experience. Mol Clin Oncol 2019;10:343-51.

9. Hanson BM, Eisenberg ML, Hotaling JM. Male infertility: a biomarker of individual and familial cancer risk. Fertil Steril 2018;109:6-19.

10. van den Driesche S, Kilcoyne KR, Wagner I, Rebourcet D, Boyle A, Mitchell R, et al. Experimentally induced testicular dysgenesis syndrome originates in the masculinization programming window. JCI Insight 2017;2:e91204.

11. Song G, Xiong GY, Fan Y, Huang C, Kang YM, Ji GJ, et al. The role of tumor size, ultrasonographic findings, and serum tumor markers in predicting the likelihood of malignant testicular histology. Asian J Androl 2019;21:196-200.

12. Bojanic N, Bumbasirevic U, Bojanic G, Vukovic I, Milojevic B, Pekmezovic T, et al: Testis sparing surgery for treatment of small testicular lesions: Is it feasible even in germ cell tumors? J Surg Oncol 2017;115:287-90.

13. Matei DV, Vartolomei MD, Renne G, Tringali VML, Russo A, Bianchi R, et al. Reliability of Frozen Section Examination in a Large Cohort of Testicular Masses: What Did We Learn? Clin Genitourin Cancer 2017;15:e689-96.

14. Connolly SS, D’Arcy FT, Bredin HC, Callaghan J, Corcoran MO. Value of frozen section analysis with suspected testicular malignancy. Urology 2006;67:162-5.

15. Shilo Y, Zisman A, Lindner A, Raz O, Strauss S, Siegel YI, et al. The predominance of benign histology in small testicular masses. Urol Oncol 2012;30:719-22. 
16. Shilo Y, Zisman A, Raz O, Lang E, Strauss S, Sandbank J, et al. Testicular sparing surgery for small masses. Urol Oncol 2012;30:18891.

17. Kachramanoglou C, Rafailidis V, Philippidou M, Bertolotto M, Huang DY, Deganello A, et al. Multiparametric sonography of hematologic malignancies of the testis: grayscale, color Doppler, and contrast enhanced ultrasound and strain elastographic appearances with histologic correlation. J Ultrasound Med 2017;36:409-20.

18. Mittal PK, Abdalla AS, Chatterjee A, Baumgarten DA, Harri PA, Patel J, et al. Spectrum of extratesticular and testicular pathologic conditions at scrotal MR imaging. Radiographics 2018;38:806-30.

19. Acar T, Efe D. Is contrast-enhanced MRI efficient in testicular infarction mimicking testicular tumor on scrotal ultrasound? Turk J Emerg Med 2015;15:192-3.

20. Hamidi N, Alijla A, Gök B, Asil E, Ardıçoğlu A, Atmaca AF. The Evaluation of Association Between Serum Neutrophil-Lymphocyte Ratio and Pathological Prognostic Factors, Development of Metastases During Follow in Stage I Germ Cell Testicular Tumor Patients. Van Tip Derg 2018;25:165-70.

21. Bolat D, Aydoğdu Ö, Polat S, Yarımoğlu S, Bozkurt İH, Yonguç T, et al. Predictive value of preoperative neutrophil-to-lymphocyte ratio on the prognosis of germ cell testicular tumors. Turk J Urol 2017;43:5561.

22. Koca O, Kutluhan MA, Akyüz M, Karaman B, Öztürk Ö, Karaman Mİ. Hematological evolution of patients with testicular cancer. J Urol Surg 2017;12:32-5.
23. Tesfamariam B. Involvement of platelets in tumor cell metastasis. Pharmacol Ther 2016;157:112-9.

24. Lou XL, Sun J, Gong SQ, Yu XF, Gong R, Deng H. Interaction between circulating cancer cells and platelets: clinical implication. Chin J Cancer Res 2015;27:450-60.

25. Sekaran P, O’Toole S, Flett M, Cascio S. Increased occurrence of disorders of sex development, prematurity and intrauterine growth restriction in children with proximal hypospadias associated with undescended testes. J Urol 2013;189:1892-6.

26. van den Driesche S, Kolovos P, Platts S, Drake AJ, Sharpe RM. Interrelationship between testicular dysgenesis and Leydig cell function in the masculinization programming window in the rat. PLoS One 2012;7:e30111.

27. Xing JS, Bai ZM. Is testicular dysgenesis syndrome a genetic, endocrine, or environmental disease, or an unexplained reproductive disorder? Life Sci 2018;194:120-9.

28. Guminska A, Oszukowska E, Kuzanski W, Sosnowski M, Wolski JK, Walczak-Jedrzejowska R. Less advanced testicular dysgenesis is associated by a higher prevalence of germ cell neoplasia. Int J Androl 2010;33:e153-62.

29. Basiri A, Movahhed S, Parvin M, Salimi M, Rezaeet GH. The histologic features of intratubular germ cell neoplasia and its correlation with tumor behavior. Investig Clin Urol 2016;57:191-5.

30. Balawender K,Orkisz S, Wisz P. Testicular microlithiasis: what urologists should know. A review of the current literature. Cent European J Urol 2018;71:310-4. 